\title{
Evaluation of exposure to phenol: absorption of phenol vapour in the lungs and through the skin and excretion of phenol in urine
}

\author{
JERZY K. PIOTROWSKI \\ Department of Biochemistry, Institute of Occupational Medicine, \\ Teresy 8, Lodz, Poland
}

\begin{abstract}
Piotrowski, J. K. (1971). Brit. J. industr. Med., 28, 172-178. Evaluation of exposure to phenol: absorption of phenol vapour in the lungs and through the skin and excretion of phenol in urine. Volunteers were exposed to phenol vapour $\left(5\right.$ to $\left.25 \mathrm{mg} / \mathrm{m}^{3}\right)$ by inhalation and through the skin, respectively, and the excretion of phenol in urine was examined.

The retention of vapour in the lungs decreased from about 80 to $70 \%$ in the course of exposure. The absorption of vapour through the whole of the skin was approximately proportional to the concentration of vapour used, the absorption rate being somewhat lower than in the lungs.

Almost $100 \%$ of the phenol was excreted in the urine within one day. The rate of excretion of phenol in the urine may be used as an exposure test which permits the absorbed dose to be estimated with a precision of about $\pm 2 \mathrm{mg}$.
\end{abstract}

The first attempts to estimate exposure to phenol by determination of its concentration in biological materials were carried out by Teisinger and FiserovaBergerova (1955b), who studied the increase of phenol in the blood of workers. More recently, Petyaev studied the changes in the blood of exposed workers using electron paramagnetic resonance (Petyaev, Khlebnikova, Malysheva, and Cherepneva, 1966).

Determination of phenol in urine has been recommended as an exposure test only for benzene (Teisinger, Skramovsky, and Srbova, 1956; Walkley, Pagnotto, and Elkins, 1961; Dutkiewicz, Piotrowski, and Kęsy-Dąbrowska, 1964). It seems likely that it could also be used as an exposure test for phenol (Bardoděj, Barodějová, Beněs, Kukačková, and Vitová, 1962) but there are no relevant data.

Of phenol administered to rabbits in a dose of $50 \mathrm{mg} / \mathrm{kg}, 90 \%$ is excreted, conjugated with sulphuric and glucuronic acids. The remaining $10 \%$ could be accounted for chiefly by hydroquinone, also conjugated (Williams, 1959). No similar data are available on man.

In the present investigation quantitative estimates were made in man of the absorption of phenol vapour and of the excretion of phenol in urine, so that urinary phenol could be related to the quantity absorbed, thus giving a test of exposure.

\section{Methods}

The experiments were performed on volunteers from the staff of the Institute (seven men aged 25 to 42 years and one woman aged 30) who had previously passed a thorough medical examination.

The exposure chamber used has been described in detail by Dutkiewicz (1960). The provision of constant temperature and humidity, necessary in experiments on skin absorption, was made automatically. The required concentrations of phenol vapour were obtained by evaporation of phenol from a vessel of constant surface area, using a constant temperature bath as the source of 
heat. During each experiment the concentration of phenol in the air was determined every hour. The concentrations were stable within any given experiment with a standard deviation of $\pm 9 \%$ of the mean.

\section{Lung absorption studies}

In order to avoid any absorption of phenol vapour through the skin, the subject remained outside the chamber and inhaled the air from inside through a face mask connected with the interior of the chamber. The concentrations of phenol in the inhaled and expired air were determined every hour. In order to avoid errors from adsorption of phenol on the connecting tubes, the air samples were taken directly from the inhalation and exhalation channels of the face mask. The volume of the expired air was measured continuously by means of a liquid gas-meter. The exposure lasted for $8 \mathrm{hr}$, with two breaks of $0.5 \mathrm{hr}$ each, beginning at 2.5 and $5.5 \mathrm{hr}$ after the start of exposure, and during which the subject was allowed to eat and to drink tea or coffee. The urine had been collected before exposure in unrestricted time intervals. In each subject urinary excretion before exposure was followed at least once for the whole day. In subsequent experiments with the same person urine samples from shorter times were taken to monitor the normal physiological levels. During exposure urine samples were taken every second hour. After exposure the urine was collected at unrestricted time intervals until the morning of the next day. For all urine samples volumes, times of collection, and specific gravities were recorded and the concentrations of phenol were determined.

\section{Skin absorption studies}

The climatic conditions in the exposure chamber were kept constant at 25 to $27^{\circ} \mathrm{C}$ and $35 \%$ humidity. Three different concentrations of phenol in the air were used, approximately 5,10 , and $25 \mathrm{mg} / \mathrm{m}^{3}$. The subject was placed in the chamber in a hammock. Usually the subject was dressed in underwear and denim overalls; for comparison, with the highest concentration of phenol vapour, studies on naked subjects were also performed. The subject was supplied with fresh air from outside the chamber so that no phenol could be absorbed through the lungs. The exposure lasted for $6 \mathrm{hr}$ with one break in the middle. Urine was collected and treated as described above. The phenol excreted in subsequent fractions within $24 \mathrm{hr}$ was summed up and, after subtraction of the physiological level, the amount excreted over $24 \mathrm{hr}$ was taken as the absorbed dose.

For the determination of the total phenol in urine the method of Porteous and Williams (1949) was used as modified for human urine by Teisinger and his colleagues (1956). To $5 \mathrm{ml}$ of urine $0.5 \mathrm{ml}$ of conc. $\mathrm{H}_{2} \mathrm{SO}_{4}$ was added and the sample was subjected to steam distillation at a rate of 2 to $3 \mathrm{ml} / \mathrm{min}$ to get $50 \mathrm{ml}$ of distillate. Depending on the expected concentration 1 to $10 \mathrm{ml}$ of the distillate was taken for colorimetric determination. For this 2.5 $\mathrm{ml}$ of sodium carbonate-borax buffer of $\mathrm{pH} \mathrm{10.15}$ was added followed by 2,6-dibromoquinone-4-chloroimide $(0.375 \mathrm{mg}$ in $0.25 \mathrm{ml}$ of alcohol). The sample was allowed to stand for $1 \mathrm{hr}$, made up to $25 \mathrm{ml}$ with water and the absorption was read at $610 \mathrm{~nm}$ on a Unicam SP-1400 colorimeter.
For air analysis, phenol was absorbed in bubblers containing $0.1 \mathrm{~N} \mathrm{NaOH}$. This solution was neutralized and phenol was determined in the same way as in urine distillates. The standard error of a single determination was $\pm 4 \%$ of the mean. The recovery of phenol from the air in one bubbler exceeded $95 \%$.

\section{Results}

Retention of phenol vapour in lungs

Individuals retained from 60 to $88 \%$ of the phenol to which they were exposed. The mean values obtained from 12 experiments in groups exposed to different concentrations of phenol (about 6 to $20 \mathrm{mg} / \mathrm{m}^{3}$ ) did not show significant differences. The average retention curve is shown in Figure 1. Retention decreased from about $80 \%$ at the beginning to approximately $70 \%$ by the end of the exposure period. There was a slight tendency for retention to increase after each break in exposure.

\section{Physiological excretion of phenol in urine}

As phenol is a normal constituent of the human urine, normal levels and their fluctuations must be found so that the excess of phenol excreted due to the exposure may be properly calculated. The results obtained on urines collected the day before exposure are shown in Figure 2a. During the day (08:00 hr to 20:00 hr) the urine excretion increased unaccompanied by a corresponding decrease of specific gravity. The same was found, only much more pronounced, during the day of exposure (Fig. 2b). As shown in Fig. 2a, between 08:00 hr and 14:00 hr the average concentrations of phenol in the urine decreased, but overall the excretion rate was higher during the day $(08: 00 \mathrm{hr}$ to $20: 00 \mathrm{hr})$ than during the night.

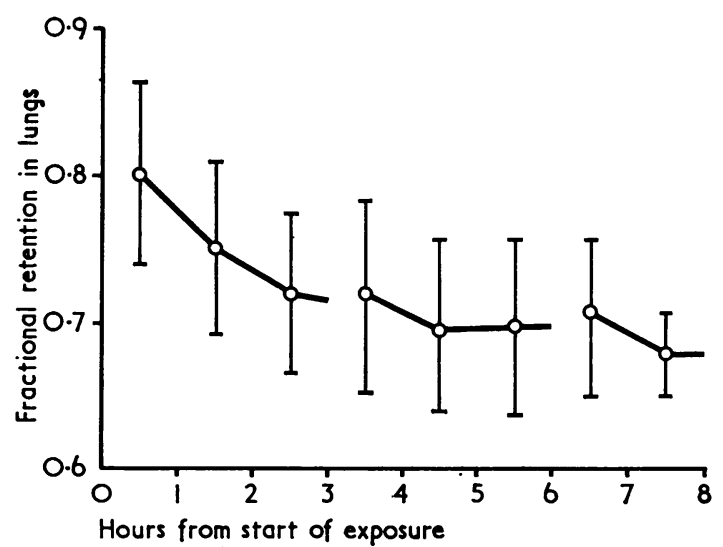

FIG. 1. Retention of phenol vapour in respiratory tract as a function of the duration of exposure. Mean values \pm standard deviations. 


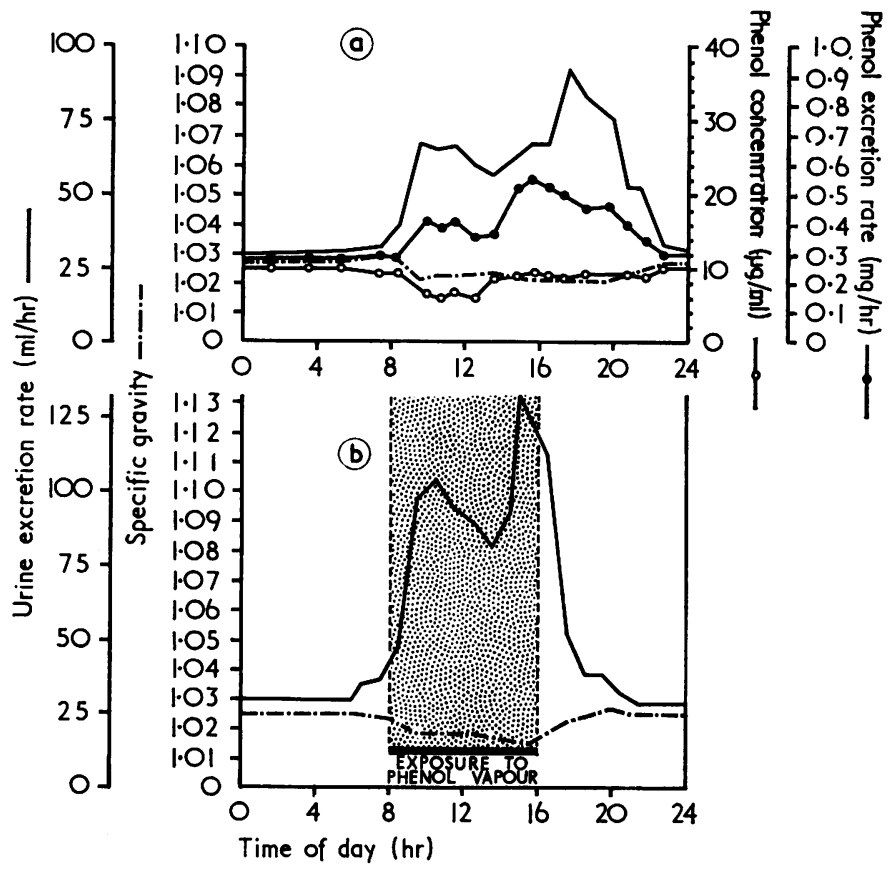

FIG. 2. (a) Analyses of urine on day preceding exposure. Mean values from 10 experiments on six subjects. (b) Rate of excretion of urine and specific gravity of urine in subjects exposed to phenol vapour. Mean values from nine experiments on five subjects.
TABLE 1

INFLUENCE OF RATE OF EXCRETION OF URINE ON Concentration and Excretion Rate of Phenol IN URINe OF NoN-EXPOSED PERsons (Means \pm Standard Deviations)

\begin{tabular}{c|c|c|c}
\hline $\begin{array}{c}\text { Urinary } \\
\text { excretion } \\
\text { rate } \\
(\mathrm{ml} / \mathrm{hr})\end{array}$ & $\begin{array}{c}\text { No. of } \\
\text { specimens }\end{array}$ & $\begin{array}{c}\text { Concentration } \\
(\mathrm{mg} / \text { litre })\end{array}$ & $\begin{array}{c}\text { Excretion } \\
\text { rate of } \\
\text { phenol } \\
(\mathrm{mg} / \mathrm{hr})\end{array}$ \\
\hline$\leqslant 20$ & 4 & $14.0 \pm 4.0$ & $0.24 \pm 0.04$ \\
$21-30$ & 11 & $12.9 \pm 5.2$ & $0.35 \pm 0.12$ \\
$31-50$ & 18 & $10.9 \pm 4.0$ & $0.37 \pm 0.14$ \\
$51-80$ & 10 & $5.4 \pm 2.1$ & $0.35 \pm 0.13$ \\
$81-120$ & 6 & $4 \cdot 5 \pm 1.2$ & $0.44 \pm 0.11$ \\
$120<$ & 5 & $3.8 \pm 2.7$ & $0.71 \pm 0.14$ \\
\hline
\end{tabular}

In Table 1 the concentrations and excretion rates of phenol used for Fig. 2a are shown, divided into groups according to the rate of urine excretion. The phenol concentration varied with the rate of excretion of urine when the whole range of the latter is considered, but the excretion rate of phenol was substantially independent from 20 to at least 80 $\mathrm{ml} / \mathrm{hr}$, i.e., within the range most often found in practice. If those results obtained with urinary excretion rates outside 20 to $120 \mathrm{ml} / \mathrm{hr}$ are omitted from Fig. 2a, the shape of the curve is barely affected. The results obtained could thus be better characterized by separate mean values and standard deviations for the night $(0.29 \pm 0.08 \mathrm{mg} / \mathrm{hr}$ from 20 determinations) and for the day $(0.44 \pm 0.18 \mathrm{mg} / \mathrm{hr}$ from 34 determinations). The average excretion of phenol may be expressed differently: daily amounts, $8 \cdot 7 \pm 2.0 \mathrm{mg} /$ day; concentrations in urine, $9 \cdot 0 \pm 5 \cdot 1$ $\mathrm{mg} / \mathrm{litre}$; concentrations corrected to standard specific gravity (1.024), $9.5 \pm 3.6 \mathrm{mg} /$ litre.

\section{Yield in urine of inhaled phenol}

In all experiments the amounts of phenol retained were calculated taking into account the concentrations in the inhaled and expired air and the volume of air respired. The amounts retained were within the range 17.8 to $62.8 \mathrm{mg}$. For estimation of the excess of phenol excreted in the urine, the amounts of phenol in the individual fractions of urine were summed up for the whole day and the individual physiological daily amount was subtracted. This 'excess' of phenol, when related to the individual value of retained phenol, gave the 'excretion yield' and this varied in the individual 12 experiments from 84 to $114 \%$, mean $99 \pm 8 \%$.

\section{Kinetics of excretion of inhaled phenol}

A typical empirical curve for the excretion of phenol, including times before, during, and after exposure, is shown in Figure 3. A rapid rise of excretion rate was seen during exposure and the maximum value was usually found directly after the end of the exposure. The excretion rate then fell, tending 


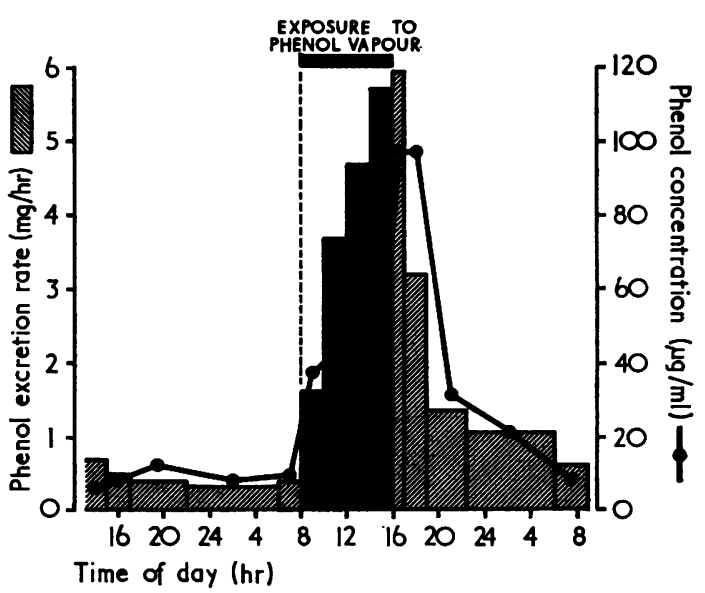

FIG. 3. Concentrations and excretion rates of phenol in urine in a subject exposed to phenol vapour in a concentration of $18.3 \mathrm{mg} / \mathrm{m}^{3}$ by inhalation.

towards the physiological ones within 24 hours.

The kinetic pattern of phenol excretion did not differ in experiments performed at various levels of exposure. The results from all the experiments could therefore be combined for further analysis. In Fig. 4 the excretion rate is expressed as a fraction of the average absorption rate during exposure, as calculated for each separate experiment, after subtraction of the individual 'physiological' excretion. A kinetic treatment is made easy by the almost $100 \%$ yield of the metabolite.

Suppose that the body behaves like a single wellmixed compartment. During the period of exposure it will receive phenol at a constant rate, $q$. The rate

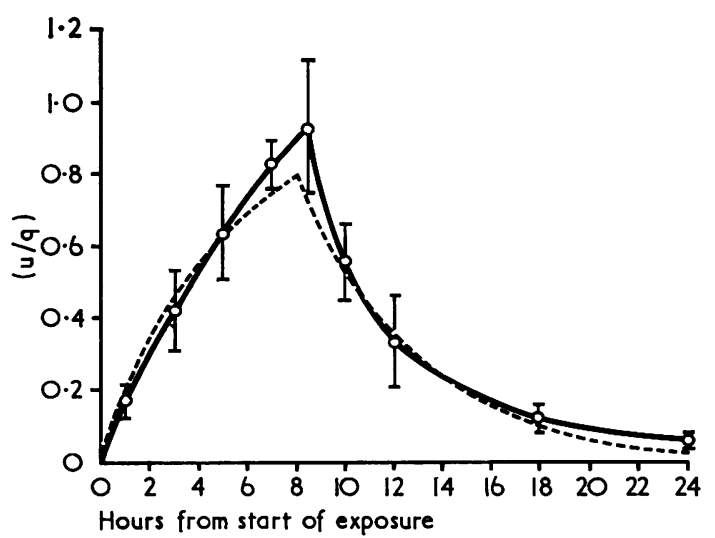

FIG. 4. Excretion rate of 'excess' phenol as a function of time of exposure and, after its termination, expressed as a fraction of absorption rate. Mean values \pm standard deviations. Dotted line-theoretical curve for $k=0.2$ hour-1. of excretion, $u$, will rise asymptotically towards $q$ during this period, according to the equation:

$$
\frac{u}{q}=1-\mathrm{e}^{-k T}
$$

where $T$ is the time measured from the start of the exposure and $k$ is the turnover constant.

Figure 4 shows the effect, with $k=0.2$ hour $^{-1}$. When exposure ceases, after time $T_{m}$, the expression $\underline{u}$ is at its maximum value, $m$. Thus: $q$

$$
m=1-\mathrm{e}^{-k T} T_{m}
$$

Thereafter the rate of excretion, as expressed by $\frac{u}{q}$ and measured from the time of cessation of exposure $\left(T-T_{m}\right)$, falls exponentially:

$$
\frac{u}{q}=m e^{-k\left(T-T_{m}\right)}
$$

Equations (1), (2), and (3) may be combined to give:

$$
\frac{u}{q}=\left(1-\mathrm{e}^{-k T_{m}}\right) \mathrm{e}^{-k\left(T-T_{m}\right)}
$$

(Piotrowski, 1970).

Figure 4 shows that an excretion coefficient $k$ of $0 \cdot 2^{-1} \mathrm{hr}$ gives a good approximation to the empirical curve. There are some discrepancies around the end of the exposure period, which may indicate that the time needed for metabolism (conjugation of phenol) delays excretion more than is calculated from a one-compartment model. These deviations were too small, however, to provide a basis for a more exact model. Additional experiments with shorter exposure periods, aiming at exaggeration of the discrepancies, also failed to provide a basis.

\section{Tests of exposure}

The excretion of the metabolite in urine can be expressed quantitatively in different units, such as total day's excretion, the concentration in urine, or the excretion rate. From the toxicological point of view any unit could be valuable if two conditions were fulfilled: (1) the correlation of the test applied with the dose received is good enough to permit the amount absorbed to be calculated; and (2) the test is a practical one for routine examinations.

In Table 2 are shown the regression coefficients of excretion in various units against exposure together with their standard deviations. The equations allow for the normal excretion of phenol conjugates. The conditions are best satisfied by the correlation of exposure with the excretion rate of phenol in the last $\mathbf{2} \mathrm{hr}$ of the day's exposure. It allows the absorbed dose of phenol to be estimated with a precision of about $2 \mathrm{mg}$. This dependence is shown in Figure 5.

Absorption of phenol vapour through the skin One of the curves, for phenol excretion following absorption through the skin only is shown in Figure 6. 
TABLE 2

Dependence between Phenol Absorbed and Excretion of Phenol in Urine, Expressed in Different UNITS

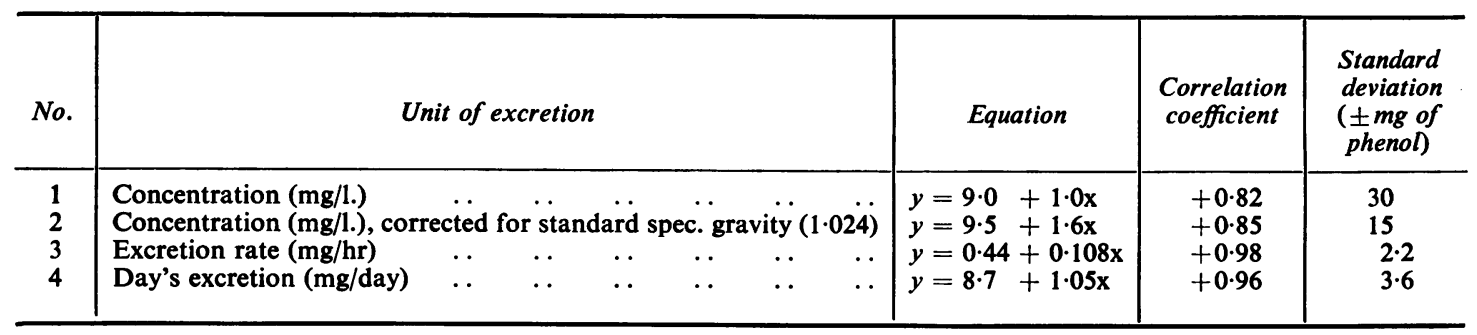

Nos. 1 to 3 refer to urine fractions collected during last two hours of exposure. $x=$ absorbed dose of phenol in mg, $y=$ excretion of phenol in urine measured in the stated unit. In the equations, values of physiological levels of urinary phenol are used.

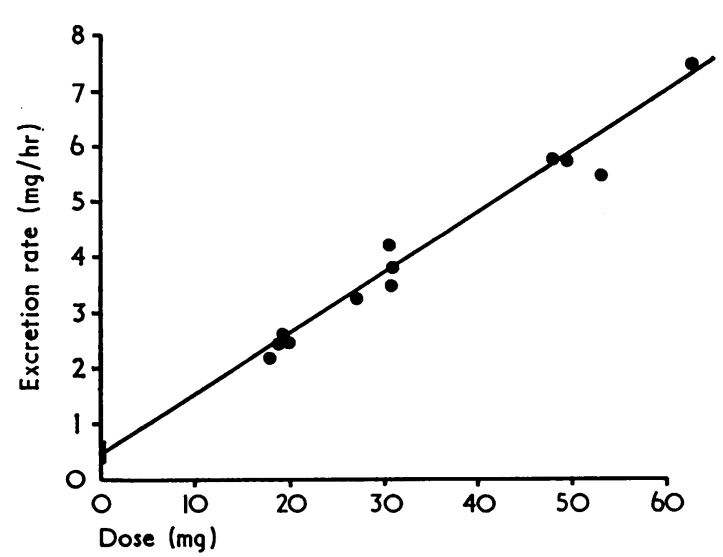

FIG. 5. Excretion rate of phenol in urine collected during last $2 \mathrm{hr}$ of exposure as a fraction of absorbed dose of phenol.

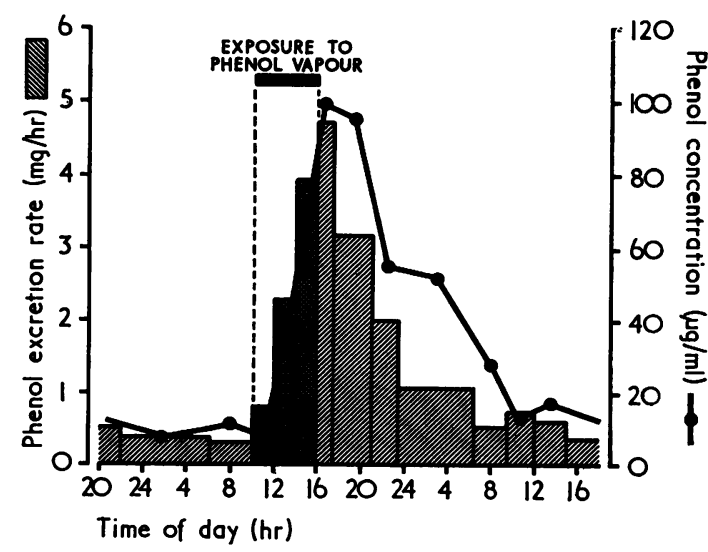

FIG. 6. Excretion of phenol in urine of a subject exposed to a concentration of $24.4 \mathrm{mg} / \mathrm{m}^{3}$ for $6 \mathrm{hr}$ with absorption through the skin.
No essential differences were seen in the kinetics of phenol excretion after skin exposure as compared with exposure by inhalation.

The results on the absorption of phenol vapour through the skin are presented in Table 3 . It is seen that the absorption rate was roughly proportional to the concentration of phenol vapour and can be characterized by the absorption coefficient of approximately $0.35 \mathrm{~m}^{3} /$ hour. This value means that the exposed subject absorbed through the skin per hour the amount of phenol contained in $0.35 \mathrm{~m}^{3}$ of air. Clothing seemed to be without protective effect.

The concentrations of phenol on the skin surface were not correlated with the concentrations of phenol in air.

TABLE 3

Absorption of Phenol Vapour through the SKIN AT DIFFERENT CONCENTRATIONS

\begin{tabular}{|c|c|c|c|c|}
\hline \multirow[b]{2}{*}{ Series } & \multicolumn{2}{|c|}{ Concentration of phenol } & \multirow{2}{*}{$\begin{array}{c}\text { Absorbed } \\
\text { doses of } \\
\text { phenol } \\
(\mathrm{mg})\end{array}$} & \multirow{2}{*}{$\begin{array}{c}\text { Absorption } \\
\text { coefficient } \\
\left(\mathrm{m}^{3} / \mathrm{hr}\right)\end{array}$} \\
\hline & $\underset{\left(m g / m^{3}\right)}{\text { In air }}$ & $\begin{array}{l}\text { On the skin } \\
\left.\left(\mu g / d^{2}\right)^{2}\right)\end{array}$ & & \\
\hline 1 & $22 \cdot 3-26 \cdot 1$ & $\begin{array}{c}33-55 \\
(46)\end{array}$ & $\begin{array}{c}31 \cdot 4-65 \cdot 1 \\
(46 \cdot 2)\end{array}$ & $\begin{array}{c}0.28-0.50 \\
(0.38)\end{array}$ \\
\hline 2 & $24 \cdot 8-25 \cdot 3$ & $\begin{array}{c}47-64 \\
(55)\end{array}$ & $\begin{array}{c}24 \cdot 8-59 \cdot 2 \\
(47 \cdot 7)\end{array}$ & $\begin{array}{c}0.20-0.48 \\
(0.38)\end{array}$ \\
\hline 3 & $9 \cdot 3-9 \cdot 7$ & $\begin{array}{c}32-50 \\
(46)\end{array}$ & $\begin{array}{c}12 \cdot 0-16 \cdot 6 \\
(13 \cdot 8)\end{array}$ & $\begin{array}{c}0.25-0.35 \\
(0.29)\end{array}$ \\
\hline \multirow[t]{2}{*}{4} & $4 \cdot 8-5 \cdot 3$ & $\begin{array}{c}14-35 \\
(24)\end{array}$ & $\begin{array}{c}5 \cdot 0-12.0 \\
(8 \cdot 6)\end{array}$ & $\begin{array}{c}0 \cdot 19-0.50 \\
(0.34)\end{array}$ \\
\hline & & & Mean & $0 \cdot 35$ \\
\hline
\end{tabular}

Conditions in the chamber were: 25 to $27^{\circ} \mathrm{C}$, humidity $35 \%$. Series 2 was performed with naked subjects, series 1,3 , and 4 with clothed subjects. The table includes values obtained in groups of three experiments in series and gives the ranges as well as the mean values (in parentheses). 


\section{Discussion}

In the present study it has been shown that phenol vapour is easily absorbed through both the lungs and the skin. It is generally accepted that phenol may also be absorbed through the skin as a result of direct contamination (Ruedemann and Deichmann, 1953; Elkins, 1959), and the data on acute intoxication confirm this view (Duverneuil and Ravier, 1962). Thus phenol is a substance exposure to which can be estimated only by tests which assess how much is absorbed. Such tests for compounds absorbed through the skin have been described by workers in this laboratory for aniline (Dutkiewicz and Piotrowski, 1961) and nitrobenzene (Piotrowski, 1967). The present study has followed the same line.

Phenol is a normal constituent of the human urine and, as found by several authors using the same analytical method as in this study, its excretion fluctuates around values close to those given in this report (Teisinger and Fiserova-Bergerova, 1955a; Teisinger et al., 1956; Hanke, Dutkiewicz, and Piotrowski, 1961; Dutkiewicz, 1964). Could, therefore, its excretion be used as a test of exposure for phenol with levels of exposure as low as the Soviet maximum allowable concentration $\left(5 \mathrm{mg} / \mathrm{m}^{3}\right.$ of air)? This appeared possible because absorption of phenol vapour through the skin contributes appreciably to the total absorbed; the yield of phenol excreted approaches $100 \%$ of that absorbed; and fluctuations in the normal levels of urinary phenol were least when these levels were expressed as excretion rates, and the excretion rate appeared the most precise unit for measuring phenol excretion due to the exposure.

The proposed exposure test is based on measurement of the excretion rate of phenol in the urine in the last $2 \mathrm{hr}$ of the daily exposure. From the rate obtained the absorbed phenol can be calculated by the equation given in Table 2. For more exact studies on very low exposures, the normal excretion rate-which in the equation is given as $0.44 \mathrm{mg} / \mathrm{hr}$ should be determined more precisely on subjects without exposure to benzene or phenol taken from the same area and having similar dietary habits as the group of workers to be studied. Probably this will not usually be necessary.

The maximum allowable dose of phenol may be calculated as a value dependent on the accepted level of the MAC by taking into account both routes of vapour absorption. Equation (5) may be used as a guide for this kind of calculation:

$$
D=C T(R V+S)
$$

where $D=$ dose absorbed $(\mathrm{mg}), C=$ concentration in air $\left(\mathrm{mg} / \mathrm{m}^{3}\right), T=$ time of daily exposure $(8 \mathrm{hr})$, $\boldsymbol{R}=$ fractional retention of vapours in lungs (for phenol about $0 \cdot 7), V=$ lung ventilation $\left(\mathrm{m}^{3} / \mathrm{hr}\right)$, $S=$ coefficient of skin absorption (for phenol
$0.35 \mathrm{~m}^{3} / \mathrm{hr}$ ). Putting $V=0.8 \mathrm{~m}^{3} / \mathrm{hr}$, the maximum allowable doses of phenol are about $35 \mathrm{mg}$ with an MAC of $5 \mathrm{mg} / \mathrm{m}^{3}$ (U.S.S.R.) and about $135 \mathrm{mg}$ with an MAC of $19 \mathrm{mg} / \mathrm{m}^{3}$ (U.S.A.) (see Cahiers de Notes Documentaires, 1969). These correspond to excretion rates at the end of the exposure period of 4.4 and $15.3 \mathrm{mg} / \mathrm{hr}$, both very much higher than the normal excretion rate of $0.44 \mathrm{mg} / \mathrm{hr}$ in our subjects.

The kinetic results presented here show that phenol is quickly excreted from the human body and that this process may be described with sufficient exactness by a simple one-compartment open model with an excretion coefficient, $k$, of $0.2 \mathrm{hr}^{-1}$. It follows that there would be little, if any, accumulation of this compound from daily exposure in industry, and that the results of the exposure test relate only to exposure on the day the urine specimen is taken.

The proposed exposure test shows a high degree of accuracy, which allows low doses of phenol to be estimated with a precision of $\pm 2 \mathrm{mg}$. It is obvious that this is attainable only on the assumption of constant exposure over the entire work-shift. In field conditions, however, the accuracy of the method will be considerably reduced due to fluctuations of the rate of absorption within the shift. From kinetic considerations it would appear that in most cases these fluctuations will lead to an underestimation of the absorbed dose.

The author wishes to thank all those colleagues from the staff of the Institute who took part in this research. The skilled technical assistance of Mrs Krystyna Kowalska is highly appreciated.

\section{References}

Bardoděj, Z., Bardodejová, E., Beněs, V., Kukačkova, V., and Vitová, A. (1962). Diuréza a fenolový test. (Diuresis and the phenol test.) Cs. Hyg., 7, 49-52.

Cahiers de Notes Documentaires (1969). No. 54,1 Trimestre

Dutkiewicz, T. (1960). Toksykologiczna komora doswiadczalna. Med. Pracy., 11, 117-124.

(1964). Quantitative exposure test for benzene. In XIV int. Congr. occup. Hlth, Madrid, 1963, Vol. 2, p. 431433. Excerpta Medica Found., Series No. 62.

on the quantitative estimation of aniline absorption in man. Pure and Applied Chemistry, 3, 319-323.

- - - and Kesy-Dąbrowska, I. (1964). Chemiczne Badania Materialu Biologicznego $w$ Toksykologii Przemysłowej, pp. 106-112. P.Z.W.L., Warsaw.

Duverneuil, G., and Ravier, E. (1962). Toxicité suraiguë du phénol par voie transcutanée. Arch. Mal. prof., 23, 830-833.

Elkins, H. B. (1959). The Chemistry of Industrial Toxicology, pp. 116-117. Chapman and Hall, London.

Hanke, J., Dutkiewicz, T., and Piotrowski, J. (1961). Wchłanianie benzenu przez skóre u ludzi. Med. Pracy, 12, 413-426.

Petyaev, M. M., Khlebnikova, M. I., Malysheva, V. V., and Cherepneva, I. E. (1966). Spektry elektronnogo paramagnitnogo resonansa krovi u rabotshikh, podvergaiushtshikhsa vozdeistvi parov fenolov. (The spectra of electron paramagnetic resonance of blood in workers 
subjected to the action of the phenol vapours). Gig. $i$. Sanit., 31, no. 10 (Oct.), pp. 17-21.

Piotrowski, J. (1967). Further investigations on the evaluation of exposure to nitrobenzene. Brit. J. industr. Med., 24, 60-65.

(1970). The application of metabolic and excretion kinetics to problems of industrial toxicology. Dept. of Health, Education and Welfare, Nat. Lib. of Med. U.S. Government Printing Office (in press).

Porteous, J. W., and Williams, R. T. (1949). Studies in detoxication. 19. The metabolism of benzene: (a) The determination of phenol in urine with 2:6-dichloroquinonechloroimide. Biochem. J., 44, 46-55.

Ruedemann, R., and Deichmann, W. B. (1953). Blood phenol level after topical application of phenol-containing preparations. J. Amer. med. Ass., 152, 506-509.
Teisinger, J., and Fiserova-Bergerova, V. (1955a). Vztah siranoveho a fenolickeho testu $v$ moci ke koncentraci benzenu ve vzduchu. Pracov. Lék., 7, 1-7.

- - (1955b). Fenol v krvi. II. Fenol v krvi u pracujicich s benzenem a fenolem. Pracov. Lék., 7, 156-160.

, Skramovsky, St., and Srbova, J. (1956). Chemickie Methody k Vysetrovani Biologickeho Materialu v Prumyslove Toxikologii, pp. 70-86. S.Z.N., Prague.

Walkley, J. E., Pagnotto, L. D., and Elkins, H. B. (1961). The measurement of phenol in urine as an index of benzene exposure. Amer. industr. Hyg. Ass. J., 22, 362-367.

Williams, R. T. (1959). Detoxication Mechanisms, 2nd ed., pp. 278-279. Chapman and Hall, London.

Received for publication June 1, 1970. 